\title{
Places, spaces and the printing press: trade interactions in Birmingham
}

Caroline Archer-Parré

Centre for Printing History \& Culture, Birmingham City University

Centre for Printing History \& Culture, Birmingham City University, The Parkside Building, 5 Cardigan Street, Birmingham B4 7RJ

caroline.archer@bcu.ac.uk

@typetweets@PrintHistory

\section{Biographical details}

Caroline Archer-Parré is Professor of Typography, Co-director of the Centre for Printing History and Culture at Birmingham City University, and the current Chairman of the Baskerville Society. With a particular interest in printing and typographic history of the English Midlands from the eighteenth to twentieth centuries, Caroline has published widely; she is the author of three books, a contributing author to numerous journals, and a regular contributor to the trade and academic press.

\begin{abstract}
With particular reference to Birmingham's printing industry, this article considers how machines and materials, crafts and skills, alongside working practices and specialist knowledge were transferred between the local printing industry and the many and various trades active in the region during the long eighteenth century. It demonstrates how the effect of place and space and the unique combination of skills and materials available in the town assisted in the technical progress of the printing industry and gave rise to specialist forms of printing, some of which are still active in the region today.
\end{abstract}

\section{Keywords}

Baskerville, Birmingham, engraving, Enlightenment, gun trade, ICI, jewellery trade, japanware, Kynoch, letterpress, metals, place, printing, space, transfer printing, type-founding, Wedgwood 


\section{Places, spaces and the printing press: trade interactions in Birmingham}

Caroline Archer-Parré

On 6 August 1945 an American B-29 bomber dropped the world's first atomic bomb over the Japanese city of Hiroshima. The explosion destroyed ninety per cent of the town and immediately killed 80,000 people, while tens of thousands more died later of radiation exposure. On 9 August a second B-29 dropped another A-bomb, this time on Nagasaki, killing 40,000 people. Six days later Emperor Hirohito, citing the shattering power of 'a most cruel bomb', announced Japan's unconditional surrender in the Second World War.1

At his home in England, Michael Clapham (1912-2002), a thirty-threeyear-old classics scholar turned printer from Birmingham, listened intently to the announcement on the radio. ${ }^{2}$ It was with a sombre sense of responsibility that he heard the news, for the bomb, which ultimately brought about the end of the Second World War, had dominated his life for four years. ${ }^{3}$

At the outbreak of hostilities Clapham was employed as Manager of the Kynoch Press (1876-1982), the in-house printer to Imperial Chemical Industries [ICI] at its Metals Division in Birmingham. ${ }^{4}$ It was while struggling with a particularly difficult printing job which required the use of photoengraving that Clapham developed an alternative way to produce the metal plates-perforated with many thousands of tiny holes of a few microns diameter-necessary for the reproduction of half-tone images. ${ }^{5}$ At the same time research scientists, also working at ICI Birmingham, were involved with the 'Tube Alloys Project', the code name for Britain's atomic bomb. ${ }^{6}$ The project, however, was held up by a

\footnotetext{
1 'Bombing of Hiroshima and Nagasaki', History < history.com/topics/world-war-ii/bombing-ofhiroshima-and-nagasaki> [accessed 13 January 2019].

2 M. Adeney, 'Clapham, Sir Michael John Sinclair: (1912-2020), printer and industrialist', Oxford Dictionary of National Biography, <https://0-www-oxforddnbcom.catalogue.wellcomelibrary.org/view/10.1093/ref:odnb/9780198614128.001.0001/odnb9780198614128-e-77377/version/0> [accessed 23 February 2020].

3 M. Clapham, Perishable Collections (London: Cloanthus Press, 1996).

4 C. Archer, The Kynoch Press: the anatomy of a printing house, 1876-1982 (London: British Library, 2000).

5 Photoengraving is a process that uses a light-sensitive photoresist applied to the surface to be engraved to create a mask that shields some areas during a subsequent operation which etches, dissolves, or otherwise removes some or all of the material from the unshielded areas. Normally applied to metal, it can also be used on glass, plastic and other materials.

${ }^{6}$ C. Brinson and R. Dove, 'Tube Alloys: the British atomic bomb project', in A matter of intelligence: MI5 and the surveillance of anti-Nazi refugees, 1933-50, (Manchester, 2014) https://www.universitypressscholarship.com/view/10.7228/manchester/9780719090790.001.0 001/upso-9780719090790-chapter-19 [accessed 23 February 2020].
} 
metallurgical challenge of unprecedented difficulty: how to separate fissile uranium from its non-explosive isotopes. It was Clapham's experiments with perforated plates for photoengraving that presented the solution and provided the breakthrough. Over the ensuing four years Clapham, alongside a team of ICI scientists, engineers, mathematicians and printers, worked to produce the membrane filter that would make the atomic bomb possible and thereby realise what was arguably the most important and consequential military breakthrough of the twentieth century.7

Five centuries earlier and five-hundred miles distant from Birmingham, Johannes Gutenberg (c. 1400-68) in Mainz, Germany, also aggregated tools and processes from local industries and applied them to his invention of printing from moveable type. His invention, which ultimately solved the problem of how to produce with speed and in quantity reading matter for an increasingly literate population, owed much to the natural resources of Mainz and the skilfulness of its metal workers. Gutenberg, who came from a family retained by the archiepiscopal mint, was a goldsmith who cut punches for trademarks, for inscriptions struck on metal-ware, and for the names and titles impressed into the spine of leather-bound books. ${ }^{8}$ It was but a short step to transfer his metalworking skills to cutting the punches necessary for the production of his printing types. In addition, Gutenberg, familiar with the properties of metals and the tools of their manufacture, appropriated this knowledge to the making of moulds, the melting of metals and the casting of amalgams necessary for making type. His printing press, however, owed its development to another industryvinification-and was, perhaps, an adaptation of the wine press which the Romans had introduced into Gutenberg's native Rhineland and which proved so useful for compressing moist and pliable substances such as paper. ${ }^{9}$ Gutenberg, drawing on the tools and techniques of the metalworkers and vintners of Mainz, brought to fruition printing from moveable type-the most significant and farreaching invention of the millennium.

It is, perhaps, a long journey from print's early relationship with goldsmithing to its contribution to the atomic bomb. Both examples, however,

7 W. J. Reader, Imperial Chemical Industries, a history: Volume 2, the first quarter century 1926-52 (London: Oxford University Press, 1975), pp. 287-97; Under Five Flags: the story of the Kynoch Works, Witton, Birmingham, 1862-1962 (Birmingham: Imperial Chemical Industries, 1962), pp. 7882.

8 H. Wallau. 'Johann Gutenberg,' in The Catholic Encyclopedia, Vol 7 ed. by C. G. Herbermann et al (New York: Robert Appleton Company, 1910); S. H. Steinberg, Five Hundred years of Printing (London: Penguin Books, 1955), pp. 22-9.

9 V. Scholderer, Johann Gutenberg: inventor of printing (London: British Museum, 1963), p. 7. 
serve to demonstrate that printing, so often regarded simply as a service industry, has, since its inception, not only borrowed from but also contributed to industries very different from its own in order to create new processes, products and methods of production. That printing from moveable type emerged in fifteenth-century Mainz was a result of the confluence of time, place and space, a triumvirate of circumstances which enabled the transfer of skills from old trades to the nascent printing industry. Five centuries later, in the crowded and abnormal times of the Second World War, it was the same trinity of circumstances which provided the fertile ground from which a Birmingham printer became intimately involved with the production of the atomic bomb. That Gutenberg and Clapham were able to respond to the demands of their time was because the spatial and temporal milieus in which they both worked facilitated critical interactions between industries and consequently enabled the transfer of skills and knowledge across disparate trades. These are not isolated instances, and between Gutenberg and Clapham there are many more examples of interactions between printing and non-allied industries.

In the most recent history, Birmingham: the workshop of the world, Malcolm Dick notes, 'there is more to find out about the role of science, skills and technology transfer in shaping industrial change' and suggests it would be interesting to explore 'how far high-quality skills may have been transferred to other industries ... such as typefounding and printing.' 10 This article addresses this suggestion. It considers how, over the course of three centuries, the town's printing industry both benefited from and contributed to the progress of other trades. It looks at the ways in which Birmingham's urban layout supported the transfer of skills, encouraged industrial interactions and enabled fluid transactions between printing and other trades; and how industrial districts and manufacturing links drew on regional resources, skills and capital for the advancement of the trade. The article concludes with suggestions as to how a critical study of such industrial interactions might shed new light on the printing trade in particular and its role in the progress of industry in general, and how it might enhance our understanding of the way in which Birmingham and its trades function.

\section{Places and spaces}

${ }^{10}$ M. Dick, 'The City of a Thousand Trades, 1700-1940' in Birmingham: the workshop of the world, ed. by C. Chinn, M. Dick (Liverpool: Liverpool University Press, 2018) p. 138. 
Place and space are significant to the progress of all trades, but, with the exception of the James Raven's Bookscape, these concepts have generally been overlooked when it comes to printing and its allied trades. ${ }^{11}$ Place and space are certainly important elements in facilitating print's relations with other industries; fundamental to forging connections between the people; and central to the transfer of knowledge, materials and techniques necessary for technological advancement. It may be useful, therefore, to consider the physical and intellectual proximity of Birmingham's various trades to that of the town's printing industry in order to establish how place and space may have assisted industrial interactions and the exchange of knowledge. For the purposes of this article 'place' is regarded as a physical entity and refers to specific locations where particular activities are conducted, such as a printing house or a manufactory. Place may also refer to a geographical area such as a particular town or district, in this case Birmingham or the Jewellery Quarter. 'Space', on the other hand, is abstract; it is the intellectual, cultural and experiential environment in which individuals or groups congregate and collaborate in order to create new things. ${ }^{12}$ 'Space' is, therefore, conjectural and relates to shared experience, knowledge, skills and cognition between trades.

That Michael Clapham became involved in the development of the atomic bomb was, in part, the result of a chance interaction facilitated by the places and spaces afforded by ICI Birmingham. It was while seconded to night air-raid duty during the Second World War and working from the top of a control tower at the centre of the ICI site, that Clapham's printing experiments came to the attention of an ICI research assistant also on air-raid duty. The tower united two individuals from unrelated trades with far-reaching results. Such unlikely meetings were encouraged by ICI and were partly a consequence of the layout of the place. ICI Birmingham employed over 20,000 people on a 250 -acre site in Witton to the north of the city. ${ }^{13}$ Witton had all the facilities of a small town, including a hospital, fire-brigade, sports facilities and social clubs, alongside various research laboratories and manufactories which made goods as diverse as ammunition, lightning fasteners and, of course, printed products. The site, a

11 J. Raven, Bookscape: geographies of printing and publishing in London before 1800 (London: British Library, 2014).

12 J. Agnew, 'Space and Place', in Handbook of geographical knowledge, ed. by J. Agnew and D. N. Livingstone (London: Sage Publishing 2011), <https://geog.ucla.edu/sites/default/files/users/jagnew/416.pdf> [accessed 19 January 2020]. 13 Under Five Flags: the story of Kynoch Works, Witton, Birmingham 1862-1962 (Birmingham: ICI, 1962). 
self-contained entity, was constructed so that the numerous trades and disciplines, researchers and labourers, management and employees worked together in close physical proximity and met both socially and professionally in common areas. The physical place helped create an intellectual space which was both innovative and self-sufficient, and which resulted in ICI Birmingham becoming a test-bed for advanced technologies and pioneering metallurgical developments. ${ }^{14}$ There was also a distinctive ICI ethos which supported the space in which experimentation and transfer of knowledge could flourish. This was reflected in social experiments, the creation of works councils and shares for employees. In addition, regular publications such as Metals Monitor and the ICI Magazine-which were more than mere staff magazines-created a sense of community through shared intelligence. 15 The intellectual, problem-solving space engendered by ICI encouraged cooperative experimentation, demolished inter-disciplinary barriers, supported unlikely collaborations and eased the transmutation of knowledge and skills across the site thereby ensuring ideas were ICI-bred rather than imported. This was the milieu in which the Kynoch press operated and, although something of an anomaly in ICI's portfolio of businesses, the Press benefited from its association with manufacturing and the scientific environment of ICI which opened up opportunities for interactions and knowledge-sharing.

The places and spaces which characterised twentieth-century ICI Birmingham, and allowed the transmutation of skills from one industry to another, were reflected more widely across the town and across the centuries. Birmingham was unlike many other English industrial centres, for example, Manchester, Leeds and Sheffield whose industrial communities were based on single trades: cotton, wool and steel. Birmingham, on the other hand, had a diverse manufacturing base primarily built on a small-workshop tradition. Edmund Burke (1729-97) described late-eighteenth century Birmingham as 'the city of a thousand trades' alluding to its diverse manufacturing base which saw the production of many different goods, mainly in a variety of metals. ${ }^{16}$ Samuel

\footnotetext{
${ }^{14}$ R. Gribben and K. Griffiths, 'Sunsets on ICI's era of imperial innovation', The Telegraph, 14 August 2007, <https://www.telegraph.co.uk/finance/markets/2814030/Sun-sets-on-ICIs-era-ofimperial-innovation.html $>$ [accessed 22 November 2019].

15 Archer, pp. 43-4.

${ }^{16}$ M. Dick, "The First Manufacturing Town: industry in Birmingham in the mid-nineteenth century, the New Illustrated Directory 1858', Revolutionary Players, $<$ https://www.revolutionaryplayers.org.uk/the-first-manufacturing-town-industry-inbirmingham-in-the-mid-19th-century-the-new-illustrated-directory-1858> [accessed 22 November 2019].
} 
Timmins (1826-1902) provided a contemporary account of local industries and the Midland hardware district describing an economy where the trades were so numerous he found it impossible to enumerate them all. ${ }^{17}$ Diverse trades worked cheek by jowl from a concentration of tightly packed industrial workshops which Charles Dickens so vividly described in Pickwick Papers:

The straggling cottages by the road side, the dingy hue of every object visible, the murky atmosphere, the paths of cinders and brick dust, the deep red glow of the furnace fires in the distance, the volumes of dense smoke issuing heavily forth from high toppling chimneys, blackening and obscuring everything around; the glare of distant lights, the ponderous wagons which toiled along the road, laden with clashing rods of iron, or piled with heavy goods-all betokened their rapid approach to the great working town of Birmingham ... The streets were thronged with work-people, the hum of labour resounded from every house, lights gleamed from the long casement windows in the attic stories and the whirl of wheels and the noise of machinery shook the trembling walls. The fires whose lurid, sullen light was visible for miles around, blazed fiercely up, in the great works and factories of the town. The din of hammers, the rushing of steam, and the dead heavy clanking of engines, was the harsh music which arose from every quarter. ${ }^{18}$

Dickens presented nineteenth-century Birmingham as a place of intense industry, characterised by its closely laid-out buildings, narrow streets and its inter-connected community of diverse workers all dependent upon the same raw materials: metal. Metalworking in steel, brass and copper was the staple trade of Birmingham. As early as the sixteenth century the town had a welldeveloped metalworking industry which required a high degree of precision and manufacturing skills: engraving, punchcutting, forging and casting. Its products were collectively referred to as 'toys' and included items such as badges, buckles and buttons; candle-sticks and snuffers; corkscrews, cruets and sugar tongs; inkstands, seals, and watch chains, as well as swords and guns. Seventeenth-century Birmingham already had a flourishing trade in guns which by the eighteenth century supported thirty-five gun and pistol makers, eight gun barrel makers and filers, five gun barrel polishers and finishers, eleven gunlock makers, forgers

${ }^{17} \mathrm{~S}$. Timmins, The resources, products and industrial history of Birmingham and the Midland hardware district (London, 1866), p. 211.

18 Charles Dicken's, Pickwick Papers, 1837 p. 605. 
and finishers, and three gun swivel and stock makers. ${ }^{19}$ By the mid-nineteenth century the trade was making millions of weapons that saw service in the Napoleonic Wars (1803-15), the American Civil War (1861-5) and the Boer War (1899-1902). Japanware, that is decorated and lacquered items made of tin, were fashionable household products first produced in Birmingham in around 1738. Made for the middling sorts, japanware was an affordable imitation of imported Eastern lacquered goods and a trade by which several manufacturers made their fortune. ${ }^{20}$ Jewellery was also part of Birmingham's wider metals industry and by 1780 the trade was thriving with in excess of thirty craftsmen working in the town fashioning items for personal adornment from base metals. The jewellers worked in Hockley, an area in the north of the town now known as the 'Jewellery Quarter', a haphazard mixture of large residences for the masters and small buildings inhabited by self-employed toymakers who used their outbuildings and garrets as workshops. ${ }^{21}$ The gunsmiths were found around Whittall Street in an area known as the 'Gun Quarter' which comprised a warren of workshops where skilled craftsmen made and engraved guns by hand.22 The Jewellery and Gun Quarters abutted one another and were adjacent to an area known informally as the 'Printers' Quarter' which ran along Newhall Street to the south and extended into the centre of town. Printing's allied trades were located in the Jewellery Quarter. ${ }^{23}$ Proximity meant the jewellers, gunsmiths and printers congregated together, sharing places and spaces, living, working and socialised in common areas. It is easy to imagine how materials, skills and working methods might be shared in these circumstances.

It is interesting to note that the same geographical and industrial profile was echoed in London's Clerkenwell which for several centuries was the centre of the capital's metalworking trades. ${ }^{24}$ The gunmakers and rifle-makers congregated around Clerkenwell Green from where, in the nineteenth-century, Hiram Maxim (1840-1916) invented the machine gun. ${ }^{25}$ Neighbouring trades included jewellers, and clock, watch and chain makers. From 1670 printers congregated around St John's Gate along with the engravers, type-founders and

\footnotetext{
19 The Birmingham Gun Barrel Proof House, <http://gunproof.com> [accessed 19 January 2019]. 20 Y. Jones, Japanned papier mâché and tinware, c. 1740-1940, (Woodbridge: Antique Collectors Club Limited, 2021), pp. 115-18.

21 S. Mason, Jewellery Making in Birmingham, 1750-1995 (Bognor Regis: Phillimore \& Co. Ltd., 1998)

22 D. Williams, The Birmingham Gun Trade (Cheltenham: The History Press, 2009).

23 British Book Trade Index (BBTI), < http://bbti.bodleian.ox.ac.uk> [accessed 9 April 2020].

24 R. Porter, A Social History of London (London: Penguin Books, 2000).

25 A. Hawley, The Amazing Hiram Maxim (Spellmount, 2001).
} 
print-makers. Bordering Clerkenwell is Hatton Garden the epicentre of London's jewellery trade since medieval times; and close to Hatton Garden is Fleet Street and St Paul's, home to printing since Wynkyn de Worde (d. 1534) set up his press in the area in 1500.26 The link between printing and jewellery is, of course, as old as printing itself, but it is interesting to observe that both London and Birmingham continued this tradition by accommodating their printers, jewellers and other metalworkers within similar boundaries. This is not coincidental and it is not beyond reason that proximity facilitated trade interactions. It certainly merits further investigation.

The places occupied by Birmingham's trades facilitated spaces of shared experience and cognition. Eighteenth- and nineteenth-century Birmingham witnessed a scientific and industrial revolution that led to the inventions that enabled widespread change in manufacturing. In addition, the so-called 'Midlands Enlightenment', ${ }^{27}$ was a cultural manifestation that created the space in which science, art and industry could exchange ideas, where social, cultural and industrial interactions could be forged which in turn facilitated rapid industrial and economic growth. ${ }^{28}$ Much has been written about this and the town's congruent industrial relations and social cohesion. Birmingham, as a manorial town, was free of the controls on trade exercised by Guilds and Corporations in the older incorporated towns. This freedom from restrictions made Birmingham particularly hospitable to newcomers and new trades and Samuel Timmins described Birmingham's environment as so open and welcoming that 'practically no restrictions, commercial or municipal were known'.29 Just as twentieth-century ICI encouraged interactions between employers and employees, so the eighteenth- and nineteenth-century town encouraged close working relations between masters and men. This in turn created what Peter Jones termed a 'knowledge economy' where ordinary craftsmen engaged in the transfer of skills and know-how, where 'fabricants' rubbed shoulders with 'savants,' and where threads of knowledge connected various craft communities-including printing. ${ }^{30}$

${ }^{26}$ C. Clair, A History of Printing in Britain, (Oxford: Oxford University Press, 1965)

27 M. Valsania and M. Dick, 'Both Sides of the Moon: Erasmus Darwin, Joseph Priestley and the West Midlands' Enlightenment', <http//:www.revolutionaryplayers.org> (accessed 21 November 2019).

${ }^{28}$ P. M. Jones, Industrial Enlightenment: science, technology and culture in Birmingham and the West Midlands 1760-1820, (Manchester: Manchester University Press, 2008).

${ }^{29} \mathrm{~S}$. Timmins, The resources, products and industrial history of Birmingham and the Midland hardware district, (London, 1866), p. 211.

30 P. M. Jones, pp. 16-17, 116-29. 


\section{Birmingham's printing trade}

Birmingham is arguably Britain's most important centre of printing outside London. ${ }^{31}$ In the eighteenth century, through its connections with William Caslon I, ${ }^{32}$ England's first native type-founder and the famous printer John Baskerville,33 Birmingham made English printing an international influence and it was Birmingham, rather than Paris, that became the focus of European printing. ${ }^{34}$ Its contribution to the printing trade, however, extends beyond Caslon and Baskerville, and the town's printers, type-founders, engravers, bookmakers and newspaper makers collectively combined to make the area a typographic force. 35

Printing is a service industry and its growth is directly linked to the community it serves. Birmingham was no exception. Between 1700 and 1750 the town's population increased from 16,000 to 42,350 and there was a commensurate rise in the number of printers supplying the town's growing demand for reading matter, from two at the start of the century to forty-two by the mid-eighteenth century. ${ }^{36}$ In the nineteenth century, industrialisation, population growth and the spread of literacy escalated the need for the printed word and the town witnessed a considerable expansion in the number of printing firms. ${ }^{37}$ Precise numbers are difficult to obtain. White's Directory of 1840 lists 133 printers, engravers and lithographers; this, however, is probably a conservative figure and other sources put the number of Birmingham's midcentury printers at around 1,200.38 Gradually, many of the small printing workshops were amalgamated or absorbed by larger firms and by the twentieth century Birmingham's printing industry had become progressively more

\footnotetext{
${ }^{31}$ Archer-Parré, 'Printing and the printed word', p. 261.

32 J. Mosley, 'William Calson the Elder', in Oxford Dictionary of National Biography $<$ oxforddnb.com/view/article/4857> [accessed 4 April 2019].

33 J. Mosley, 'John Baskerville, (1706-1775) printer and typefounder', in Oxford Dictionary of National Biography. https://0-www-oxforddnbcom.catalogue.wellcomelibrary.org/view/10.1093/9780198614128.001.0001/odnb9780198614128-e-1624, [accessed 24 February 2020]

34 S. Morison, Four Centuries of Fine Printing: two hundred and seventy-two specimens of the work of presses established between 1465 and 1924, (London: Ernest Benn, 1960) p. 40.

35 J. Hill, Book Makers of Old Birmingham: authors, printers and booksellers, (Birmingham: Cornish Brothers, 1907).

${ }^{36} \mathrm{~J}$. Hinks and M. Bell, 'The English provincial book trade: an evaluation of the evidence from the British Book Trade Index', in The Cambridge History of the Book in Britain, Volume V, 1695-1830, ed. by M. Suarez and M. Turner, (Cambridge: University Press, 2009) pp. 335-51.

37 B. W. E. Alford, 'Business Enterprise and the growth of the commercial letterpress printing industry. 1850-1914', in Business History, Volume 7, Issue 1, (Taylor and Francis, 1965), pp. 1-14. 38 White's Directory of the town and borough of Birmingham, (Sheffield, 1849); British Book Trade Index (BBTI), <bbti.bodleian.ox.ac.uk>.
} 
specialised, for example in commercial stationery, trade cards and highly decorated promotional literature ${ }^{39}$ Letterpress was the town's dominant printing technology; however, the invention of transfer printing and the early adoption of this technique, first by the ceramic industry and later the retail clothing trade, ensured the area's pre-eminence in transfer printing. ${ }^{40}$

While Birmingham had a small number of book printers who supplied a national and international market, most of town's printers ran jobbing houses and were wholly dependent upon the immediate community for business. ${ }^{41}$ To sustain the trade the town needed to generate a significant amount of work in order to keep the presses occupied. It seems that there was insufficient business as nearly all Birmingham's small jobbing printers supplemented their income by offering allied services such as book dealing and print selling, publishing, bookbinding, paper and ink making, or by operating circulating libraries. In addition, over half the town's printers ran supplementary, non-allied, businesses such as auctioneering, button-making and brewing, or offered their services as chemists, victuallers, hosiers, tavern-keepers, estate agents or singing-masters; others were engaged in gun-engraving, sword embossing, enamelling, ceramics and japanning. ${ }^{42}$ James Hawkins, letterpress printer, doubled as a locksmith and his competitor, James Belcher also offered his services as a brush-maker; Joseph Hornblower, engraver and etcher, supplemented his income with glass-staining, while his fellow engraver William Duncalf made buttons; George and Warwick Savage, 'artistic' printers imported and sold French camel hair pencils. ${ }^{43}$ While the connection between printing and many of the secondary trades is far from apparent, some, such as engraving, had more obvious intersections with printing and not only shared skills but also tools and materials.

It is clear that interactions between Birmingham's jobbing printers and other trades were taking place at a grass-roots level. The extent of the interactions is less clear, but some of the skills, materials, tools and techniques exercised by these multi-skilled, multi-tasking printers may have been modified

${ }^{39}$ C. Archer-Parré, 'Printing and the Printed Word', in Birmingham: the workshop of the word, ed. by C. Chinn and M. Dick, (Liverpool: Liverpool University Press, 2016), p. 272.

40 J. Grayson, 'Imperfect enamel printed surfaces: interpreting marks of eighteenth-century midlands craftsmanship', and J. Gilbert, 'Better dressed than Birmingham'? Wholesale clothing catalogues and the communication of mass fashion 1920s to 1960s', in this volume;

41 M. Twyman, Printing, 1770-1970: an illustrated history of its development and uses in England,

(New Castle DE: Oak Knoll Press, 1998), p. 15.

42 British Book Trade Index, <bbti.bodleian.ox.ac.uk> [accessed 1 November 2018].

43 British Book Trade Index (BBTI), < http://bbti.bodleian.ox.ac.uk> [accessed 9 April 2020]. 
and moved between occupations. History does not record the practices of these small, seemingly unimportant printers but there was probably a "knowledge economy' that operated between the various craftsmen albeit in ways which have 'left few traces in the industrial world.' 44 That such transfers could take place was a result of the places and spaces provided by Birmingham's permissive trade environment, alongside the physical structure of the small workshops whose arrangement and proximity aided trade collaborations.

Cross-fertilisation between trades was a two-way process, and just as Birmingham's jobbing printers connected with diverse industries those from outside the printing trade contributed to the progress of the typographic trade. In his directory of Birmingham inventors, Richard Prosser (1838-1918) demonstrates that patents relating to printing were not uncommon. ${ }^{45}$ Most applications came, however, from outside the trade. James Watt (1736-1819), the famous engineer, patented a machine for copying letters; John Gregory Hancock (1775-1815), diesinker, registered a patent for a new method of embossing paper; the banker, economist and political campaigner Thomas Attwood (1783-1856) conceived a new design for calico-printing rollers, as did the brass founder Benjamin Cook; William Harold, merchant, designed a papermaking machine; and John Bird, gentleman, devised a new formula for printer's ink and other pigments. Perhaps the most prolific of all Birmingham's inventors was the American-born engineer Dr William Church (1778-1863) who, between 1822 and 1850, registered no fewer than fifteen patents. His inventions ranged from steam carriages ${ }^{46}$ to bedsteads, from furnaces to knife sharpeners and also included three patents for printing machines and other inventions relative to printing. His designs included a press for printing and delivering sheets in a pile; a contraption for numbering and printing railway tickets; and a type composing and casting machine, thought to be the first of its kind. ${ }^{47}$ The London Journal of Arts and Sciences described Church's inventions as being at 'the front of those valuable and useful inventions which adorn the present age.'48 Church was ahead of his time and the description of his composing and casting machine would have certainly been recognised by turn-of-the-century printers as a

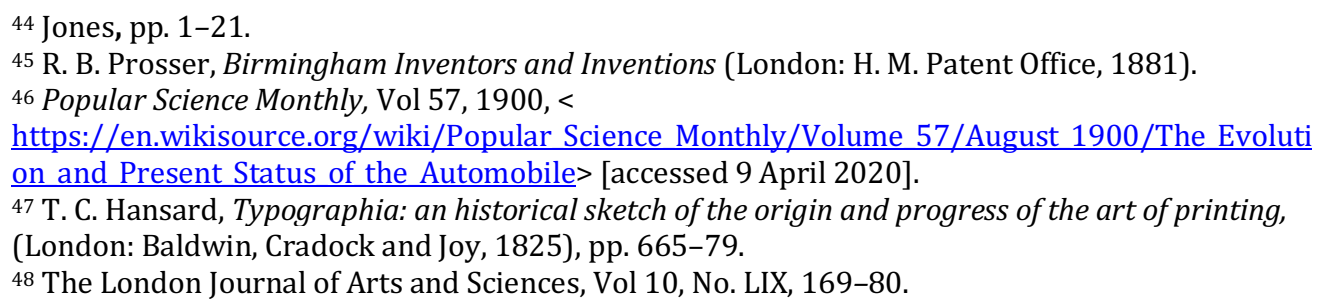


precursor to the Linotype and Monotype composing and casting machines. That Church chose to build his prototype machine in Birmingham was, so he said, because it was only Birmingham that afforded the unique combination of resources, raw materials, skills and knowledge to execute his vision. ${ }^{49}$

While none of the aforementioned inventors had a background in printing, each had the perspicacity to comprehend a problem, the tenacity and skills to apply their knowledge across disciplines, trades and communities, access to materials, and a network of connections to make things happen. The places of Birmingham trade were critical to the development and progress of their inventions. A study of the individual patents would provide useful clues to the processes and materials used by the inventors which would indicate the range of skills needed to bring their inventions to fruition. Less apparent are the social, intellectual and business structures that enabled these men to straddle trades. This article looks at four individuals-the printers William Caslon and John Baskerville and the manufacturers Josiah Wedgwood and George Kynochfor clues as to how trade connections might have operated.

\section{William Caslon: gun engraver and typefounder}

William Caslon (1692-1766), England's first native type-founder of note was born in Cradley, Worcestershire, and trained as an engraver of ornamental gunlocks and gun-barrels. In 1706 Caslon was apprenticed to Edward Cookes, a London metalworker who specialised in the engraving of guns for the Board of Ordnance. It was probably a relative among the Birmingham gun-makers that recommended Caslon be indentured to Cookes as the Board of Ordnance placed most of its orders for the metal parts of military small arms with Birmingham makers. ${ }^{50}$ Between 1716 and 1719 Caslon was himself official engraver to the Ordnance and it is estimated that, over the course of three years, he engraved around 8,400 musket locks. ${ }^{11}$ One 'considerable branch of his employment' was, like Gutenberg before him, the cutting of tools for bookbinders and the chasing of silver plate. In around 1720, Caslon added the cutting of typographic punches to his repertoire. ${ }^{52}$ Caslon's introduction to typefounding came about when the

${ }^{49}$ M. A. McCorison, 'Dr William Church of Vershire, Vermont', Notes on printing and graphic arts, (1956), pp. 34-41.

50 J. Mosley, 'The early career of William Caslon' in Journal of the Printing Historical Society, (London, 1967), pp. 66-81.

51 B. Hunnisett, Engraved on steel: history of picture production using steel plates, (Farnham: Ashgate Publishing, 1988), p. 12.

52 J. Nichols, Biographical and literary anecdotes of William Bowyer, Printer, (London: By and for the author, 1782) p. 585. 
London printer, William Boyer, spotted Caslon's 'uncommonly neat' lettering on a book in the shop of Daniel Brown, bookseller near Temple Bar, and invited him to cut some type. ${ }^{33}$ Caslon turned to punch cutting at a fortuitous time for England's printing trade as just twenty years earlier, in 1695, state control over printing had been lifted. ${ }^{54}$ For nearly 140 years the country's native type founding was restricted in production, poor in design and inferior in manufacture. Any type of any quality had to be imported from the Continent, usually Holland. England's typographic redemption came not from within the printing trade but from the gun trade as Caslon transferred the skills he had acquired in engraving muskets to the cutting of punches for printing. The gunlock engraver from Cradley rescued English type founding from the mire into which it had sunk, gave the country a range of letters equal to anything available on the continent, and spawned a dynasty of typefounders who continued to trade for more than 300 years. ${ }^{55}$ That Caslon should transfer his skills to the production of punches for printing type was the result of the convergence of time, place and space, coupled with a network of contacts, fortuitous circumstances, and the adroit adaptation of skills, materials and tools from one industry for the benefit of another.

\section{John Baskerville: japanner and printer}

John Baskerville (1707-75), ${ }^{56}$ a close contemporary of Caslon, was an eighteenth-century Birmingham printer, industrialist and Enlightenment figure who changed the course of type design. Baskerville was the 'complete printer' who not only designed one of the world's most historically important typefaces, but also experimented with casting and setting type, improved the construction of the printing press, developed a new kind of paper and refined the quality of printing inks. His typographic experiments put him ahead of his time, had an international impact and did much to enhance the printing and publishing industries of his day. Baskerville was, however, a printer neither by training nor trade. He arrived in Birmingham in about 1726, 'having trained in no occupation'

\footnotetext{
53 Nichols, p. 585.

54 R. Astbury, 'The renewal of the licensing act in 1693 and its lapse in 1695', in The Library, fifth series, vol. xxxiii, no. 4, (London: The Bibliographical Society, 1978), pp. 298-322.

55 C. Clare, A history of printing in Britain, (London: Cassell, 1965), pp. 190.

56 J. Mosley, 'Baskerville, John (1706-1775)', Oxford Dictionary of National Biography, <http://0www.oxforddnb.com.catalogue.wellcomelibrary.org/view/article/1624> [accessed 14 November 2015].
} 
initially working as a writing master and carving headstones. ${ }^{57}$ By 1740 he began manufacturing japanware by which he made his fortune. ${ }^{58}$ It was not, however, until around 1750, aged forty-three, that Baskerville turned to printing. Like Caslon before him, Baskerville succeeded in his career-change by transferring the skills and knowledge he had gained in his earlier trades to his newfound interest in printing.

In the first instance Baskerville applied his understanding of lettersgained through his experience as a writing master and letter carver-to the creation of his typeface. For his new type to print with accuracy Baskerville had to consider all aspects of the printing process, including the construction of the press, the manufacture of the paper and the recipe for his inks. Japanning was technically useful to his printing experiments. In 1742 Baskerville took out a patent for 'Machinery for Rolling and Grinding Metal Plates or Veneers' for use in the production of his japanware, the purpose of which was to produce thin metal plates that were precisely made, 'exactly true and level,' and of even gauge. 59 The beds and platens of eighteenth-century hand-presses were usually constructed of wood and, as a consequence, impressions were often uneven. 60 To address this problem Baskerville appears to have applied his technique for rolling metal plates to the manufacture of brass platens for his presses in order to present a completely flat printing surface, which allowed the even printing of his type. Baskerville also transferred japanning processes to his experiments with ink and paper. In manufacturing his varnish Baskerville used lamp-black, linseed oil and amber rosin. It may have been his been familiarity with these substances that prompted Baskerville to experiment with them in the manufacture of his printing inks for it was these ingredients, according to T. C. Hansard, which made Baskerville's printing ink unusually black and lustrous. ${ }^{6}$ In addition, it is probable that the coloured pigments he used in his japanware

57 W. Hutton, 'An account of John Baskerville, printer', in The Edinburgh Magazine or literary miscellany, (Edinburgh: J. Sibbald,1785), pp. 375; R. Straus and R. Kirkup Dent, John Baskerville: a memoir, (London: Chatto \& Windus, 1907), pp. 4.

58 Y. Jones, Japanned papier mâché and tinware c. 1740-1940, (Woodbridge: Antique Collectors Club Ltd., 2012), pp. 115-18.

${ }^{59}$ Patent number 582 granted to John Baskerville 16 January 1742, for 'Machinery for Rolling and Grinding Metal Plates of Veneers'.

${ }^{60} \mathrm{~A}$ flat surface made of brass, and which is the part of a printing press on which the sheet of paper is placed and takes the impression.

61 Y. Jones, 'John Baskerville: Japanner of "Tea Trays and other Household Goods"' in John Baskerville: art and industry of the enlightenment, ed. by C. Archer-Parré and M. Dick, (Liverpool: Liverpool University Press, 2016), pp. 71-86; T. C. Hansard, Typographia: an historical sketch of the origin and progress of the art of printing; with practical directions for conducting every department in an office: with a description of stereotype and lithography, (London, 1825), p. 310-13. 
were also used to make his highly original marbled papers. ${ }^{62}$ Finally, Baskerville had acquired a liking for smooth shiny finishes so evident on his Japanware. It was perhaps natural, therefore, that he designed a 'smoothing press', consisting of two big copper cylinders, so that his papers could be given a polished and even finish. ${ }^{63}$

Baskerville was an experimenter who possessed a prodigious amount of 'pure' scientific knowledge, an uncommon capacity for technical skills, aesthetic ability and boundless curiosity, which he exercised for the benefit of his trades. Baskerville did not, however, work in isolation and his Birmingham contacts provided him with the experiential space necessary to his success. Along with Thomas Salt, Samuel Ford, Richard Conquest and William Sawyer, Baskerville was a partner in the Smethwick Brass Co., a foundry making brass ingots. ${ }^{64} \mathrm{~A}$ shrewd and propitious association, which gave him access both to the raw materials and the network of associations necessary for his japanning and printing businesses. Baskerville's two trades required the skills and experience of others, and he had both personal and professional connections with many of Birmingham's progressive thinkers and makers including the manufacturer Matthew Boulton (1782-1809), the engineer James Watt (1736-1819) and bookseller, author, and paper merchant William Hutton (1723-1815).65 He was part of a group of experimenters, manufacturers and artisans who shared ideas, encouraged practical experiments and supported each other's projects. ${ }^{66}$ Baskerville also employed several skilled artisans. Birmingham's trades of metal engraving meant there was a steady supply of craftsmen whose skills transferred easily to the printing trade and from this body of artisans Baskerville may have recruited the labour which ensured the punches and matrices

62 B. McKay and D. Patterson, 'John Baskerville's decorated papers' in John Baskerville: art and industry of the enlightenment ed. by C. Archer-Parré and M. Dick, (Liverpool: Liverpool University Press, 2016), pp. 151-65.

63 J. Dreyfus, The survival of Baskerville's punches (Cambridge: Cambridge University Press, Privately Printed, 1949; J. Dreyfus, 'Baskerville's method of printing' in Signature, vol. 12 (new series), (London, 1951).

${ }^{64}$ London Gazette, issue 13157, (London, 12 December 1789), p, 784.

$65 \mathrm{~J}$. Tann, 'Matthew Boulton, (1728-1809) manufacturer and entrepreneur' Oxford Dictionary of National Biography, <https://0-www-oxforddnb-

com.catalogue.wellcomelibrary.org/view/10.1093/ref:odnb/9780198614128.001.0001/odnb9780198614128-e-2983> [accessed 23 February 2020]; J. Tann 'James Watt, (1736-1819) engineer and scientist', Oxford Dictionary of National Biography, <https://0-www-oxforddnbcom.catalogue.wellcomelibrary.org/view/10.1093/ref:odnb/9780198614128.001.0001/odnb9780198614128-e-28880> [accessed 23 February 2020]; C. R. Elrington, 'William Hutton, (17231815) historian', Oxford Dictionary of National Biography, < https://0-www-oxforddnbcom.catalogue.wellcomelibrary.org/view/10.1093/ref:odnb/9780198614128.001.0001/odnb9780198614128-e-14317> [accessed 23 February 2020].

66 J. Uglow, The Lunar Men: the friends who made the future, (London: Faber \& Faber, 2003). 
necessary for the development of his types were sharp and neatly struck in metal and made to the exacting standards he required. ${ }^{67}$

Baskerville ran his japanning and printing businesses in tandem from his home at Easy Hill to the north-west of Birmingham. He operated from a single location in just the same way the small jobbing printers in town ran multiple businesses from a single site. Like his less-celebrated contemporaries, Baskerville multi-tasked, moving between one trade and the other on a daily basis taking with him skills, materials and techniques from one trade and using them for the benefit of the other. This was made possible firstly because Baskerville's place of work allowed free movement between the two workshops enabling the transfer of processes and materials from his japanning business to his printing venture; secondly he employed skilled craftsmen whose abilities were transferable across both trades; thirdly japanning and printing shared raw materials; and finally his association with the town's leading manufacturers whose advice may have helped Baskerville formulate cross-disciplinary approaches to trade. Just like William Church, a century later, Baskerville succeeded as it was only in Birmingham that he could find the combination of resources, skills and knowledge needed to execute his work.

\section{Josiah Wedgwood: pottery and transfer printing}

Birmingham's extensive community of engravers exercised their skills across multiple trades, including that of copperplate printing, a process that began in Birmingham in 1740 when George Anderton (trading dates c. 1740-63) established himself as the town's first copperplate engraver. ${ }^{68}$ In the printing trade, engraving was used as a method by which to reproduce prints or illustrations on paper by incising lines into a plate of copper. Engravers were skilled craftsmen, capable copyists who could interpret the lines of the artist and render their design in metal ready for printing. It was a process appropriate for particularly refined work and Birmingham's eighteenth-century copperplate engravers applied their skills to the production of musical scores, maps and more elaborate work such as invitations or trade cards where lettering was combined with decorative elements. ${ }^{69}$ Engraving was also an essential skill for the region's pottery trade.

67 J. Dreyfus, 'Baskerville's method of printing,' Signature, vol. 12, New Series (1951), xii, 44-49. 68 T. B. Reed, A History of the Old English Letterfounders, (London: Faber \& Faber,1952) p. 341. ${ }^{69}$ M. Twyman, Printing, 1770-1970: an illustrated history of its development and use in England, (London: British Library 1998) p. 6. 
The Potteries is an area north-west of Birmingham now defined by the boundaries of modern-day Stoke-on-Trent. From the seventeenth to nineteenth centuries, however, the Potteries comprised six villages-Burslem, Fenton, Hanley, Longton, Stoke and Tunstall - which collectively became the centre of ceramic production and home to such famous names as Wedgwood, Minton, Spode and Doulton. The pottery and printmaking worlds were already closely related with large numbers of prints being copied by painters on to pottery, especially porcelain, for which prints, including book illustrations, were the main source of images. Engraving, coupled with a process known as 'transfer printing' reduced the need for expensive and time-consuming hand-painting and therefore speeded-up the process of manufacture, reduced production costs, and brought the price of ceramic goods within the reach of everyman. Transfer printing relied upon the process of conveying a design from an engraved copperplate onto pottery by means of either tissue paper or a sheet of gelatine. ${ }^{70}$ Designs were engraved on copper plates, which were printed on paper using metallic oxide inks, and then pressed while wet against the unfired piece of china. The design was fixed when the item was fired. ${ }^{71}$ The first known patent for 'printing, impressing and reversing upon enamel and china from engraved, etched and mezzotinted plates and from cutting on wood and mettle' was taken out in 1751 by John Brooks, a Birmingham engraver. The process was further developed when, in 1856, two Birmingham men, Samuel Tearne and G. Richmond, introduced a colour transfer process. 72 The quality of the transfer depended principally on the skill of the printer, with little finished by hand.

The ceramics industry was a pioneer in the use of transfer printing and a clearly identifiable sector of the local printing trade emerged to cater for the production of transfers for ceramics. Large numbers of printers, particularly etchers and engravers, sprang up across the Potteries to service the ceramics trade. The British Book Trade Index (BBTI), indicates that over the course of a century Burslem was home to an astonishing 194 printers and Shelton supported ninety-eight. ${ }^{73}$ As printing is a service industry the appearance of so many printers in such a small area can only be accounted for by the demands of

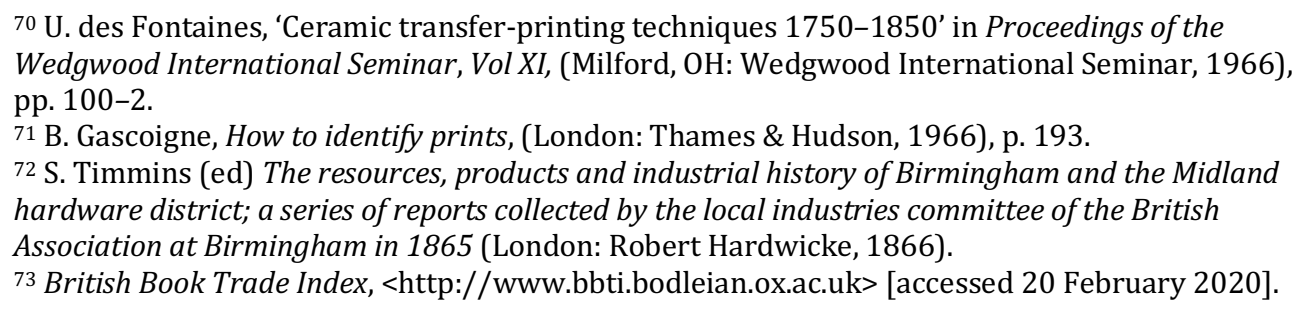


the pottery industry. Some manufacturers, such as Josiah Wedgwood, the famous potter and entrepreneur, established their own in-house printers for the purpose of producing transfers. ${ }^{74}$

Hundreds of workers, mainly women, were employed in the transfer of images to pottery. Working in teams of three, 'one cut-up the transfers, moistened them from behind, and positioned them with their printed side down on an item; a second rubbed them down, working from the centre of the design so that any bubbles could be released; and a third coaxed the backing paper away by rubbing it with a damp sponge. ${ }^{75}$ Michael Twyman noted that these women were referred to as 'lithographers', a term borrowed from the printing industry, although their work had nothing to do with the making of lithographs. ${ }^{76}$ Similar language transfer, or language sharing, can be seen between the printing and gun trade, where printers refer to full-points as 'bullets', where the smallest of type sizes and minutest of percussion caps are both termed 'nonpareil', and both industries test their products through 'proofing'. This raises interesting etymological questions relating to the transfer of language and terminology between one trade and another.

The close proximity of the pottery and printing trades may have been responsible for the development of yet another printing technique: the copying machine. Increasingly businesses felt the needed to keep duplicates of correspondence and other documents, and copying machines were able to reproduce manuscripts in limited quantities, eliminated dependence on hand duplication thereby saving time and money. Ralph Wedgwood (1766-1837), cousin to Josiah, created an 'apparatus for producing duplicates.' Known as the Manifold Writer it was patented in 1806. The basic technique involved sandwiching 'carbonated' paper (made by soaking paper in printer's ink) between writing paper and thin duplicating paper. Rather than using a pen for writing, the Manifold Writer required a stylus known as an 'everlasting pen.' Ralph claimed that up to six impressions could be made at once if the technique was properly applied, and, in a letter to his daughter, claimed to have written '400 pages quarto' with his everlasting pen.77 Ralph predicted the 'invention will

\footnotetext{
74 Wedgwood Museum archive, Barlaston, Stoke on Trent (WMA), MS L31-5023-5035, MS L345941-5962, MS L133-26834-26835.

75 M. Twyman, A history of chromolithography: printed colour for all, (London: British Library, 2013), pp 640.

76 Twyman, pp. 640.

77 WMA, MS E56-31510.
} 
be of a public utility' and the Royal Institution, London, recommended it as an invention worthy of public attention, declaring:

Mr Ralph Wedgwood having in confidence exhibited to us his Pocket Secretary \& Everlasting Pen (now called the Patent Manifold Writer) for the sanction of our opinion we have the satisfaction to state that we have made trial of the same and in their recommendation have to observe that we consider the invention worthy of Public Attention. ${ }^{78}$

By 1807 , just two years after the patent, Ralph made $£ 11,000$ profit, announcing 'All the principal secretaries of state have adopted this invention'. It is not known from where Ralph took his inspiration for his Manifold Writer, but the link between transfer printing used in the pottery trade and the development of his copying machine is unmistakable. It is tempting to speculate that it was Josiah's own transfer printing works that may have been the motivation behind Ralph's invention. Whatever the relationship between transfer printing and the copying machine, Wedgwood created an interesting circle of technology transfer whereby techniques originally specific to printing were next applied to pottery and then adapted and recycled back to the printing industry to create a new process of copying. ${ }^{79}$

\section{George Kynoch: printing and the appliance of science}

From its birth in 1876 to its demise just over a century later, the Kynoch Press, Birmingham was a constituent part of Kynoch Ltd., a Birmingham business whose interest was not in printing but small-arms, percussion caps and explosives. Kynoch Ltd., was established by an émigré Scot, George Kynoch (1834-91), whose marriage to Helen, the daughter of Samuel Birley, a wealthy local jeweller, provided him with the necessary money to fund his company. ${ }^{80}$ The links between the early Press and the gun and jewellery trades are,

78 WMA, MS E27-19534.

${ }^{79} \mathrm{M}$. Cook, "Towards a history of recording technologies: the damp-press copying process, in Journal of the Society of Archivists, Vol. 32 No. 1, (Abingdon: Taylor \& Francis, 2011), pp. 35-49; W. B. Proudfoot, The origins of stencil duplicating, (London: Hutchinson \& Co., 1972); B. Rhodes and W. Wells Streeter, Before photocopying: the art and history of mechanical copying 1780-1938, (New Castle, DE: Oak Knoll Press, 1999); R. Schils, How James Watt invented the copier: forgotten inventions of our great scientists, (New York: Springer, 2012), pp. 37-42; C. Archer-Parré, 'Lettercopy press 1780', The power to change the world: James Watt (1736-1819) in fifty objects, (History West Midlands, 2019), pp. 67-8.

80 D. H. L. Back, 'George Kynoch 1834-91) ammunition manufacturer', Oxford Dictionary of National Biography < https://0-www-oxforddnbcom.catalogue.wellcomelibrary.org/view/10.1093/ref:odnb/9780198614128.001.0001/odnb9780198614128-e-48741> [accessed 19 December 2019]. 
therefore, significant. Over the course of a century Kynoch Ltd. expanded considerably and went on to be a substantial element of the mighty ICI, the largest company in the British Empire, whose interests covered, among other things, dyestuffs, explosives, chemicals, metals, paints, and plastics. ${ }^{81}$ The Press, a component part of the company, was swept along with the expansion finding its progress inextricably tied to the parent company. This association with manufacturing and science could have been detrimental to the Press; instead it proved advantageous with the Kynoch Press contributing to the development of many processes and products. ${ }^{82}$ Post-war advances in ICI technology brought about unaccustomed printing surfaces-plastics, various metals and fabrics made from polyester such as Crimplene and Terylene-with which the Press was in a prime position to experiment and, working in tandem with ICI scientists, the Press experimented with the new substrates to create new methods of production. ${ }^{83}$ Hexagon Digest (1948-58), published by ICI Dyestuffs Division and printed by the Kynoch Press, is one of many such collaborations between ICI printers and its scientists. ${ }^{84}$ The Digest was designed to show the fade properties of individual colours hour-by-hour, the diminishing quality of their intensity and their colour characteristics. To demonstrate this the Press worked in close collaboration with ICI Dyestuffs to produce accurate colour proofs which necessitated innovative optical simulation methods and a new colour-masking system for use in photo-mechanical reproduction processes. ${ }^{85}$ That these experiments took place was a direct result of the relationship between knowledge, materials, techniques available in-house at ICI and their success then went on to influence colour printing techniques across the wider industry.

\section{Conclusion}

Place and space were important elements in facilitating print's relationship with other industries; fundamental to forging connections between the people; and central to the transfer of knowledge, materials and techniques necessary for technological advancement. Printing is much more than a service industry. It is also a trade which has actively contributed to and benefited from its

\footnotetext{
${ }^{81}$ Archer, Kynoch Press.

82 Archer, Kynoch Press, p. 9.

${ }^{83}$ Archer, Kynoch Press, p. 95.

${ }^{84}$ Archer, Kynoch Press, p. 70.

85 Archer, Kynoch Press, p. 70.
} 
relationships with other industries. In Birmingham, printing had a particularly strong connection with the town's metal manufacturers. This interaction was encouraged by combined places of work and spaces of thought, which enabled tacit knowledge, skills and technology to be shared, reshaped and reused by a particularly metamorphic workforce. Trade interactions are seen, inevitably, through the lens of major manufacturers such as Caslon, Baskerville, Wedgwood and Clapham for whom material evidence or documentary verification is readily available. The big names provide top-level evidence of trade collaboration. However, capturing the extent and precise nature of industrial exchanges, and quantifying their impact among lesser-known craftsmen is less easy. This is partly because the individual, unknown artisans who comprised the bulk of the town's workforce have left few identifiable traces either of themselves or their work. How to uncover the lives and working methods of the myriad of minor workers whose individual biographies may be largely untraceable is more problematic. Prosopography is one possible solution. There is sufficient evidence available in local directories, newspapers, historical maps, and adverts by which a picture of common characteristics can be built. Mapping the locations of individual trades in order to understand their relative proximity of the town's printers, would help confirm the importance of place to trade interactions.

Supplement this with a matrix of common materials, tools, techniques, resources and suppliers and this would create a picture of the processes that may have evolved between the various trades. Add to this trade links that were forged through matrimony and patrimony and an understanding of the importance of networks to the development of trade may also be discerned. Finally, a consideration of trade terms would shed light on the linguistic association between the various industries. Collectively these approaches enable new ways of seeing how Birmingham's trades developed, how industrial change was shaped and provide an enhanced understanding of how towns function. 